\title{
BUDAYA ORGANISASI, KOMUNIKASI, DAN MOTIVASI SEBAGAI DETERMINASI TERHADAP KINERJA PEGAWAI KANTOR CAMAT BATAM KOTA
}

\author{
Surya Akbar, Zatul Akmam dan Reza Efendi
}

Program Studi Ilmu Administrasi Negara STIA Indragiri

Jl. Azki Aris, Rengat. Kode Pos 29318. Telp. (0769) 22458

\begin{abstract}
This study aimed to get empirical evidence of the influence of organizational culture, communication, and motivation on employee performance in Batam City District Office. In the stages of testing in this study using the sampling method used is the census. The sample in this study was 43 Employees Head Office Batam City. Methods of data collection conducted by questionnaire. Hypothesis testing is performed using linear regression models and test the $T$-statistic. Hypothesis testing is done by using SPSS software. Based on the results of testing the first hypothesis, it is known that the organizational culture significantly influence employee performance Batam City District Office. And the results of the second test, it is known that the communication is not significant to the performance of the staff of the Head of Batam. And a third test results, it is known that motivation has a significant influence on employee performance Batam City District Office.
\end{abstract}

Keywords: Organizational Culture, Communication, Motivation, Performance

\section{PENDAHULUAN}

Globalisasi dunia menuntut bangsa Indonesia agar dapat sejalan dengan perkembangan zaman. Bukan hanya dari segi peningkatan infrasruktur yang memadai saja, tapi lebih cenderung sebagai bangsa besar yang memiliki kemampuan intelektual tinggi yang menjadi corak peradaban maju agar masyarakat Indonesia dapat dikenal oleh bangsa lain dalam upayanya meningkatkan kualitas kehidupan. 
Banyak langkah yang dapat ditempuh dalam hal meningkatkan kualitas kehidupan, baik melalui peningkatan komptensi softskill ataupun hardskill. Kompetensi softskill ini antara lain mengeni mentaalitas, karakteristik bahkan kemampuan interpersonal seperti komunikasi yang baik. Sedangkan komptesi hardskill lebih cenderung mengarah kepada peningkatan kemampuan teknis seperti pendidikan dan pelatihan (Darmayanti, 2014 : 2)

Berkaitan dengan itu semua, pemerintah melalui Kementrian Pemberdayaan Aparatur Negara dan Reformasi Birokrasi Republik Indonesia berusaha secara berkesinambungan melakukan pembenahan pada aparatur Pegawai Negeri Sipil di seluruh Indonesia dalam rangka peningkatan kualitas kinerja agar dapat bekerja secara profesional untuk memberikan pelayanan prima kepada masyarakat. Hal ini dilakukan untuk mewujudkan pemerintahan yang baik dan pemerintahan yang bersih. Berbagai macam hambatan pasti akan ditemui oleh para individu organisasi ini untuk bisa bekerja dengan baik sehingga kinerja mereka dapat diterima dengan baik oleh organisasi maupun masyarakat yang memerlukan. Banyak faktor yang dapat mempengaruhi kinerja antara lain: kepemimpinan, fasilitas kerja, lingkungan kerja, insentif, budaya kerja, komunikasi, jabatan, kompensasi, dan masih banyak yang lainnya.

Organisasi adalah salah satu entesitas sosial yang terkoordinasi secara sadar, terdiri dari dua orang atau lebih dengan batasan yang relatif teridentifikasi, yang berfungsi secara berkelanjutan untuk mencapai seperangkat sasaran bersama.

Bagi organisasi yang memberikan pelayanan kepada publik, tentu saja kinerja pegawai itu dapat dilihat dari bagaimana organisasi tersebut dapat memberikan pelayanan prima kepada publik, seperti pada Kantor Camat Batam Kota mengenai pelayanan tertib administrasi kependudukan yang berlaku di Kota Batam. Penelitian ini akan mengkaji bagaimana pengaruh Budaya Organisasi, Komunikasi dan Motivasi terhadap Kinerja Pegawai.

Komunikasi merupakan hal penting dalam perilaku organisasi, komunikasi tidak hanya proses penyampaian informasi dan berita yang dapat dilihat, didengar, dimengerti, tetapi proses penyampaian informasi yang menyeluruh termasuk di dalamnya perasaan dan sikap dari yang menyampaikan informasi tersebut. Namun yang sering terjadi disini adalah komunıкasi yang salah, ketika berkumpul mereka 
menggunakan komunikasi dengan salah seperti ngerumpi (membicarkan hal-hal yang tidak penting).

Motivasi yang ada pada seseorang merupakan kekuatan yang akan mewujudkan suatu perilaku dalam mencapai tujuan kepuasan dirinya pada tipe kegiatan yang spesifik, dan arah tersebut porsitif dengan mengarah mendekati objek yang menjadi tujuan.

Batam Kota adalah sebuah Kecamatan di Kota Batam, Kepulauan Riau Oleh masyarakat Batam Kecamatan Batam Kota lebih dikenal dengan istilah Batam Center. Di Kecamatan inilah terletak pusat pemerintahan Kota Batam, Alun-alun dan Masjid Raya Batam. Mega Wisata Ocarina juga terletak di Kecamatan ini. Lokasinya yang strategis di tengah-tengah Pulau Batam membuat Kecamatan Batam Kota berkembang pesat menjadi kawasan industri dan pemukiman yang ramai Darmayanti, (2014 : 5).

Berdasarkan latar belakang di atas, maka penulis tertarik untuk melakukan penelitian dengan judul "Budaya Organisasi, Komunikasi, dan Motivasi Sebagai Determinasi Terhadap Kinerja Pegawai Pada Kantor Kecamatan Batam Kota.

\section{Tujuan Penelitian}

1. Untuk mengetahui determinasi Budaya Organisasi terhadap Kinerja Pegawai di Kantor Camat Batam Kota

2. Untuk mengetahui determinasi Komunikasi terhadap Kinerja Pegawai di Kantor Camat Batam Kota

3. Untuk mengetahui determinasi Motivasi terhadap Kinerja Pegawai di Kantor Camat Batam Kota

4. Untuk mengetahui determinasi Budaya Organisasi, Komunikasi, dan Motivasi secara simultan terhadap Kinerja Pegawai di Kantor Camat Batam Kota.

\section{Manfaat Penelitian}

\section{Manfaat Teoritis}

Dari penelitian ini penulis berharap memperoleh banyak manfaat untuk menambah wawasan dan ilmu pengetahuan yang bisa disesuaikan dengan pekerjaan yang dijalani berdasarkan teori yang diperoleh dari kampus. 
Hasil penelitian ini kiranya dapat menjadi referensi bagi rekan-rekan peneliti lainnya di masa yang akan datang mengenai Budaya Organisasi, Komunikasi, dan Motivasi.

\section{Manfaat Praktis}

Hasil penelitian ini diharapkan bisa menjadi sumbangan pemikiran untuk membantu memecahkan masalah-masalah pelayanan dan dalam pengambilan keputusan di wilayah kerja Kecamatan Batam Kota.

\section{KERANGKA TEORITIS}

\section{Budaya Organisasi}

Budaya adalah hasil karya cipta manusia yang dihasilkan dan telah dipakai sebagai bahagian dari tata kehidupan sehari-hari. Suatu budaya yang dipakai dan diterapkan dalam kehidupan selama periode waktu yang lama akan mempengaruhi pola pembentukan dari suatu masyarakat, seperti kebiasaan rajin bekerja, dan kebiasaan ini berpengaruh secara jangka panjang yaitu pada semangat rajin bekerja yang terus terjadi hingga diusia senja, begitu pula sebaliknya jika sudah terbiasa malas dan tidak suka bekerja maka itu juga akan terbawa hingga pada saat menjadi kakek nenek (Fahmi, 2013:49).

Organisasi adalah sistem peran, aliran aktivitas dan proses (pola hubungan kerja) dan melibatkan beberapa orang sebagai pelaksana tugas yang didesain untuk mencapai tujuan bersama. Menurut Robbins dalam Torang (2013:25) organisasi adalh suatu entitas sosial yang terkoordinasi secara sadar, terdiri dari dua orang atau lebih dengan batasan yang relatif teridentifikasi, yang berfungsi secara berkelanjutan untuk mencapai seperangkat sasaran bersama.

Organisasi berasal dari kata organ (sebuah kata dalam bahasa Yunani) yang berarti alat). Oleh karen itu kita dapat mendefinisikan organisasi sebagai sebuah wadah yang memiliki multi peran dan didirikan dengan tujuan mampu memberikan serta mewujudkan keinginan berbagai pihak, dan tak terkecuali kepuasan bagi pemiliknya.

Dalam lingkup organisasi, budaya organisasi sering diartikan sebagai sekumpulan sistem nilai yang diakui dan dibuat oleh semua anggotanya. Menurut Robbins dalam Mulyadi (2015:95) budaya organisasi adalah "Istilah yan dipakai 
untuk memuat rangkaian variabel-variabel perilaku yang mengacu kepada nilai-nilai, kepercayaan-kepercayaan, dan prinsip pokok yang berperan sebagai suatu dasar bagi suatu sistem manajemen organisasi”.

Pada tingkat organisasional, budaya organisasi adalah asumsi-asumsi, keyakinan-keyakinan, nilai-nilai, dan persepsi yang dimiliki bersama oleh anggota organisasi yang membentuk dan mempengaruhi sikap, perilaku, serta petunjuk dalam memecahkan masalah (Gibson, Ivannicevicdan Donnelly, dalam Torang 2013:107). Menurut Luthans (2007) budaya organisasi adalah tata nilai \& norma yang menuntun perilaku jajaran organisasi.

Budaya organisasi mencerminkan persepsi umum yang dilakukan oleh seluruh anggota organisasi. Karenanya dapat diharapkan bahwa individu dengan latar belakang berbeda atau pada tingkat yang berbeda dalam organisasi akan cenderung menjelaskan budaya organisasi dengan terminologi yang sama. Namun, hal tersebut tidak berarti bahwa dalam suatu organisasi hanya terdapat suatu budaya tunggal. Di dalam budaya organisasi masih terbuka kemungkinan adanya satu atau lebih subkultur. Kebanyakan organisasi besar mempunyai dominant culture dan sejumlah subculure.

Mengacu pada beberapa pendapat diatas, dapat disimpulkan bahwa budaya organisasi adalah belief, value, norma, dan system yang membentuk dan mewarnai perilaku pimpinan dan anggota organisasi sehingga menjadi kebiasaan yang sulit diubah. Budaya adalah katup pengaman untuk mengatur beroperasinya organisasi melalui landasan nilai dan keyakinan setiap individu yang kemudian melembaga (menjadi norma kerja).

\section{Komunikasi}

Komunikasi merupakan salah satu elemen penting dalam kehidupan organisasi. Fungsi manajemen mulai dari perencanaan, pengorganisasian, pengarahan sampai dengan pengawasan semuanya melibatkan komunikasi. Komunikasi membantu para anggota organisasi untuk mencapai tujuan individu maupun tujuan organisasi, merespons dan mengimplementasikan perubahan organisasi, mengkoordinasikan aktivitas organisasi, serta ikut berperan dalam semua tindakan organisasi yang relevan. Komunikasi efektif juga membantu organisasi dalam mencapai sasaran atau tujuannya. 
Setiap manajer selalu berhubungan dengan proses komunikasi. Manajer berhasil adalah mereka yang dapat menjalankan komunikasi dengan baik dan efektif, yaitu dapat menjadi penerima sekaligus sebagai komunikator yang efektif. Komunikasi dikatakan efektif apabila mendapat respons yang diharapkan dari audience. Komunikasi yang efektif merupakan pemahaman bersama antara individu yang menyampaikan pesan dengan individu yang menerima pesan.

Komunikasi berasal dari bahasa latin, yaitu communis yang artinya bersama. Komunikator berusaha untuk mencari kebersamaan dengan si penerima pesan. Komunikasi/communication dapat di definisikan sebagai transisi/transtion informasi dan pemahaman melalui penggunaan simbol-simbol bersama dari satu orang atau kelompok kepada pihak lain. Simbol-simbol tersebut dapat verbal maupun non verbal (Ivancevich, et. al., $2007: 69$ )

Komunikasi adalah suatu proses penyampaian dan penerimaan berita atau informasi dari seseorang ke orang lain. Suatu komunikasi yang tepat akan terjadi apabila penyampai berita menyampaikan secara tepat sebuah informasi kepada penerima dan tidak terjadi ganguan atau distorsi (Herlambang, 2014:77).

\section{Motivasi}

Motivasi kerja adalah sebagai keadaan yang mendorong keinginan individu untuk melakukan kegiatan-kegiatan tertentu untuk mencapai keinginannya. Motivasi yang ada pada seseorang merupakan kekuatan yang akan mewujudkan suatu perilaku dalam mencapai tujuan kepuasan dirinya pada tipe kegiatan yang spesifik, dan arah tersebut psoitif dengan mengarah mendekati objek yang menjadi tujuan (Sunyoto, 2013:1).

Motivasi untuk bekerja ini sangat penting bagi tinggi rendahnya produktivitas perusahaan. Tanpa adanya motivasi dari para karyawan untuk bekerja sama bagi kepentingan perusahaan, maka tujuan yang telah ditetapkan tidak akan tercapai. Sebaliknya, apabila terdapat motivasi yang tinggi dari para karyawan, maka hal ini merupakan suatu jaminan atas keberhasilan perusahaan dalam mencapai tujuannya (Gitosudarmo dalam Sutrisno, 2009:111).

Motivasi mempersoalkan bagaimana cara mendorong gairah kerja bawahan, agar mereka mau bekerja keras dengan memberikan semua kemampuan dan 
keterampilan untuk mewujudkan tujuan perusahaan (Hasibuan dalam Sutrisno, 2009:110).

Wexley dan Yukl dalam Sutrisno (2009:110), memberikan batasan mengenai motivasi sebagai the process by which behavior is energized and directed.

Menurut Robbins (dalam Sutrisno, 2009:111), mengemukakan motivasi sebagai suatu kerelaan berusaha seoptimal mungkin dalam pencapaian tujuan organisasi yang dipengaruhi oleh kemampuan usaha memuaskan beberapa kebutuhan individu.

Motivasi merupakan proses psikologis yang membangkitkan dan mengarahkan perilaku pada pencapaian tujuan atau goal-directed behavior (Kreitner dan Kinicki dalam Wibowo, 2014:322).

Danim dalam (Torang, 2013:58) mengasumsikan motivasi sebagai aktivitas individu untuk menentukan kerangka dasar tujuan dan penentuan perilaku untuk mencapai tujuannya.

Menurut Saroso dalam Fahmi (2013:107) motivasi adalah suatu set atau kumpulan perilaku yang memberikan landasan bagi seseorang untuk bertindak dalam suatu cara yang diarahkan kepada tujuan spesifik tertentu.

\section{Kinerja}

Menurut Amstrong dan Baron dalam Fahmi (2013:127-128) mengatakan kinerja merupakan hasil pekerjaan yang mempunyai hubungan kuat dengan tujuan strategis organisasi, kepuasan konsumen dan memberikan kosntribusi ekonomi.

Kinerja menurut Aguinis dalam Fattah (2014:13) adalah performance is about behavior or what employees do, not about what employees produce or the outcomes of their work. Maksudnya kinerja adalah tentang perilaku atau apa yang dilakukan oleh karyawan, bukan tentang apa yang diproduksi atau yang dihasilkan dari pekerjaan mereka.

Kinerja didalam suatu organisasi dilakukan oleh segenap sumber daya manusia dalam organisasi, baik unsur pimpinan maupun pekerja. Banyak sekali faktor yang dapat mempengaruhi sumber daya manusia dalam menjalankan kinerjanya. Terdapat faktor yang berasal dari dalam diri sumber daya manusia sendiri maupun dari luar dirinya (Wibowo, 2013:69). 
Kinerja menurut Mc Clelland dalam Torang (2013:74) menentukan beberpa karakteristik kinerja yaitu; bertanggung-jawab dalam pemecahan masalah menetapkan tujuan, ada umpan balik dan dapat diandalkan.

Untuk menilai kinerja individu dalam organisasi, Ravianto dalam Torang (2013:74) menetapkan beberapa kriteria yaitu: kompetensi indvidu tentang pekerjaan, kemampuan individu dalam membuat perencanaan dan jadwal pekerjaannya, pengetahuan indvidu tentang standar mutu pekerjaan, produktivitas individu (kualitas dan kuantitas kinerja), kompetensi teknis atas pekerjaannya, ketergantungan kepada orang lain, kemampuan berkomunikasi, kemampuan kerjasama, kedipsiplinan dan kemampuan menyampaikan gagasannya dalam rapat, kemampuan mengelola pekerjaan serta kepemimpinan.

\section{Kerangka Berpikir}

Budaya organisasi mencerminkan persepsi umum yang dilakukan oleh seluruh anggota organisasi. Karenanya dapat diharapkan bahwa individu dengan latar belakang berbeda atau pada tingkat yang berbeda dalam organisasi akan cenderung menjelaskan budaya organisasi dengan terminologi yang sama. Namun, hal tersebut tidak berarti bahwa dalam suatu organisasi hanya terdapat suatu budaya tunggal. Di dalam budaya organisasi masih terbuka kemungkinan adanya satu atau lebih subkultur. Kebanyakan organisasi besar mempunyai dominant culture dan sejumlah subculure.

Setiap manajer selalu berhubungan dengan proses komunikasi. Manajer berhasil adalah mereka yang dapat menjalankan komunikasi dengan baik dan efektif, yaitu dapat menjadi penerima sekaligus sebagai komunikator yang efektif. Komunikasi dikatakan efektif apabila mendapat respons yang diharapkan dari audience. Komunikasi yang efektif merupakan pemahaman bersama antara individu yang menyampaikan pesan dengan individu yang menerima pesan.

Motivasi untuk bekerja ini sangat penting bagi tinggi rendahnya produktivitas perusahaan. Tanpa adanya motivasi dari para karyawan untuk bekerja sama bagi kepentingan perusahaan, maka tujuan yang telah ditetapkan tidak akan tercapai. Sebaliknya, apabila terdapat motivasi yang tinggi dari para karyawan.

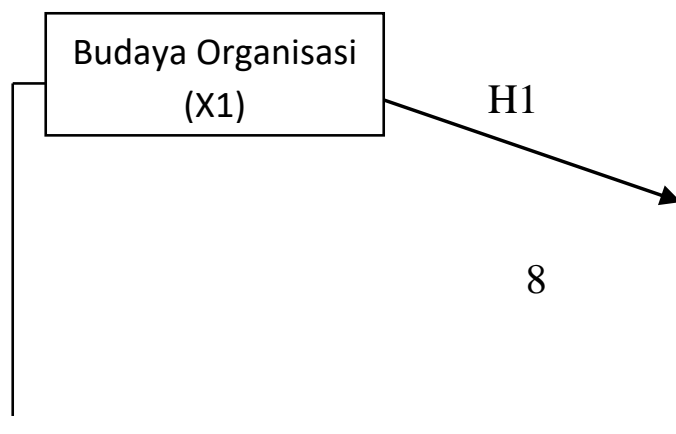




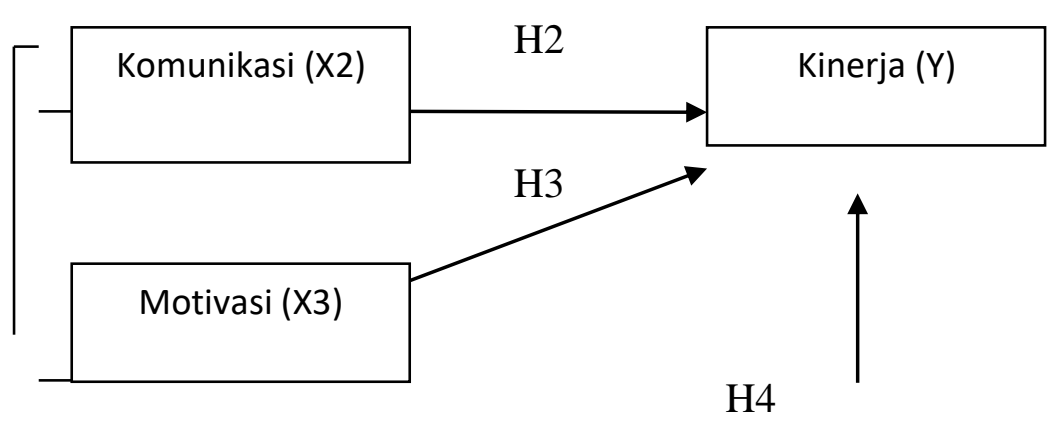

Gambar 1. Kerangka Pemikiran

\section{Hipotesis}

1. Budaya Organisasi mempunyai determinasi terhadap Kinerja Pegawai pada Kantor Camat Batam Kota

2. Komunikasi sebagai mempunyai determinasi terhadap Kinerja Pegawai pada Kantor Camat Batam Kota

3. Motivasi mempunyai determinasi terhadap Kinerja Pegawai pada Kantor Camat Batam Kota

4. Budaya Organisasi, Komunikasi dan Motivasi mempunyai determinasi secara simultan terhadap Kinerja Pegawai pada Kantor Camat Batam Kota.

\section{Populasi, Sampel, dan Penarikan Sampel}

Sugiyono (2015:148), menyatakan populasi adalah wilayah generalisasi yang terdiri atas objek atau subjek yang mempunyai kualitas dan karakteristik tertentu yang ditetapkan oleh peneliti untuk dipelajari kemudian ditarik kesimpulannya.

Populasi (N) dalam penelitian ini adalah Pegawai Kantor Camat Batam Kota sebanyak 43 pegawai. Maka penarikan sampel dalam penelitian ini menggunakan teknik sensus. Aspek penelitian ini terdiri dari tiga variabel yaitu variabel bebas (variabel independen) dan variabel terikat (variabel dependen). Variabel bebas (variabel independen) adalah Budaya Organisasi, Komunikasi, dan Motivasi, sedangkan variabel terikat (variabel dependen) adalah Kinerja pegawai.

\section{Teknik Analisis Data}

Teknik Analisis Data dilakukan untuk memanfaatkan komputer, melalui program SPSS for windows 21. 


\section{HASIL PENELITIAN DAN PEMBAHASAN}

\section{Gambaran Umum Objek Penelitian}

Kecamatan Batam Kota efektif beroperasi pada tanggal 3 Juni 2006 yang seiring dengan dilantiknya Camat Batam Kota, Sekretaris Kecamatan dan 6 (enam) Lurah yang berada di wilayah Kecamatan Batam Kota.

Untuk Kecamatan Batam Kota yang wilayah kerjanya merupakan Pemekaran dari Kecamatan Nongsa, Juga bergabung 1 (satu) Kelurahan yang sebelumnya berada dalam wilayah kerja Kecamatan Batu Ampar yaitu wilayah Kelurahan Bukit Jodoh yang berubah namanya menjadi Kelurahan Sungai Panas.

Kecamatan Batam Kota terletak pada sebelah Timu Laut dari wilayah Pulau Batam atau wilayah Barelang dengan posisi 1.000-1.18 Lintang utara dan 104.000-104,150, dan mempunyai luas wilayah sekitar 46,808 $\mathrm{Km}^{2}$ dengan rincian sebagai berikut: $38,964 \mathrm{Km}^{2}$ (luas daratan) dan 7,844 Km² (luas lautan).

Kecamatan Batam Kota terletak pada sebelah Timur laut dari wilayah Pulau Batam yang memiliki batas antara lain:

Sebelah Utara berbatas dengan $\quad$ : Kecamatan Bengkong

Sebelah Selatan berbatasan dengan : Kecamatan Sungai Beduk

Sebelah Timur berbatasan dengan $\quad$ Kecamatan Nongsa

Sebelah Barat berbatasan dengan : Kecamatan Lubuk Baja dan Kecamatan Sekupang.

Pemerintahan Kecamatan Batam Kota pada tahun 2006 adalah merupakan tahun pertama dalam penyelenggaraan pemerintahan yaitu setelah pemekaran wilayah, kecamatan dan kelurahan dimana sarana prasarana yang ada di kecamatan ini dapat dikategorikan masih baru yang mana semua perangkat dimulai dari awal, dimana sampai dengan saat ini secara kwantitas dan kualitas pelayanan dirasakan cukup merata dengan di bangunnya beberapa sarana dan prasarana sampai dengan level pemerintahan terendah yakni Kelurahan, Pelaksanaan Pemerintahan Kecamatan berpedoman pada Undang-undang nomor 43 tahun 1999 tentang pokok-pokok kepegawaian yang dijelaskan berdasarkan lembaran Negara RI tahun 1999 nomor 169, serta lembar tambahan Negara RI dengan Nomor 3890, dengan berpedoman dan atas aturan yang ada itu maka susunan kepegawaian yang dilaksanakan sebagai penunjang pelaksanaan pemerintahan daerah yang tersusun berdasarkan Undang- 
Undang Nomor 22 Tahun 1999 tentang pemerintahan daerah yang dijelaskan berdasarkan lembaran Negara RI nomor 60 dan lembaran tambahan Negara RI denga Nomor 3839 serta undang-undang nomor 32 tahun 2004 tentang Pemerintahan Daerah Pelaksanaan sebagai pedoman dan panduan dimana teknis dan pengaturannya diserahkan pada masing individu kepala wilayah yang bersangkutan untk berkreasi dan berinovasi guna menuju pelayanan prima pada masyarakat (public service) yang pada akhirnya bertujuan untuk mensejahterakan masyarakat, mencerdaskan masyarakat serta peningkatan budi pekerti masyarakat yang adil dan makmur.

\section{Hasil Pengujian}

Program yang digunakan untuk menguji validitas dan realibilitas instrumen adalah program computer. Statistical Program For Social Science (SPSS) versi 21.

Dari hasil validitas untuk 41 item pernyataan dari 4 variabel, diperoleh semua item mempunyai korelasi skor probabilitas $\mathrm{r}<0,05$ (sig.2-tailed $<0.05$ ) sehingga instrument untuk Budaya organisasi, Komunikasi, Motivasi, dan Kinerja pegawai memenuhi uji validitas. Ketentuan ini berdasarkan panduan SPSS dan Analisis Jalur Jemmy Rumenggan dan Team (2010).

Uji instrument yang valid di uji denan menggunkn Cronbch Alpha, dapat dilihat dari Tabel 1 berikut:

Tabel 4.15

Hasil Uji Reliabilitas

\begin{tabular}{|c|c|c|}
\hline Variabel & Nilai Reliabilitas & Status \\
\hline Budaya Organisasi (X1) & 0,760 & Reliabel \\
\hline Komunikasi (X2) & 0,755 & Reliabel \\
\hline Motivasi (X3) & 0,728 & Reliabel \\
\hline
\end{tabular}

Sumber : SPSS 21, data primer yang diolah bulan Agustus 2016Menurut Rumengan (2010) Hasil Cronbach Alpha > 0.60, maka nilai yang di dapatkan reliabilitas

\section{Uji Multikolinearitas}

Uji multikolinieritas digunakan untuk menguji apakah model regresi ditemukan adanya korelasi anatara variabel bebas. Cara untuk menilainya adalah dengan melihat nilai faktor inflasi varian (VIF) yang tidak melebihi 4 atau 5 (Hitnes 
dan Montogomery dalam Rumengan dkk,2010). Berikut hasil uji multikolinearitas denan menggunakan nilai VIF, dapat dilihat dari tabel 2.

Tabel 4.16

Multikolinearitas

Coefficients $^{\mathrm{a}}$

\begin{tabular}{|c|c|c|c|c|c|c|c|}
\hline \multirow[t]{2}{*}{ Model } & \multicolumn{2}{|c|}{$\begin{array}{l}\text { Unstandardized } \\
\text { Coefficients }\end{array}$} & \multirow{2}{*}{$\begin{array}{c}\text { Standardized } \\
\text { Coefficients }\end{array}$} & \multirow[t]{2}{*}{$\mathrm{t}$} & \multirow[t]{2}{*}{$\begin{array}{l}\mathrm{Si} \\
\text { g. }\end{array}$} & \multicolumn{2}{|c|}{$\begin{array}{l}\text { Collinearity } \\
\text { Statistics }\end{array}$} \\
\hline & B & Std. Error & & & & $\begin{array}{l}\text { Toler } \\
\text { ance }\end{array}$ & VIF \\
\hline (Constant) & 9,900 & 5,365 & & 1,845 &, 073 & & \\
\hline Budaya & ,470 & , 137 & (569 & 3,430 & , 001 & ,485 & 2,062 \\
\hline Komunikasi &,- 345 & ,178 &,- 339 & - &, 060 & , 436 & 2,294 \\
\hline Motivasi & ,513 & , 157 & ,472 & 3,262 &, 002 & 637 & 1,570 \\
\hline
\end{tabular}

a. Dependent Variable: Kinerja

Sumber : Data primer yang diolah, 2016.

Berdasarkan tabel 2, ketiga variabel independen yakni Budaya Organisasi, Komunikasi dan Motivasi memiliki nilai VIF dalam batas toleransi yang ditentukan (tidak melebihi 4 atau 5), sehingga tidak terjadi multikolinieritas dalam variabel independen penelitian ini.

\section{Uji Koefisien Derterminasi}

Koefisien determinasi merupakan besaran yang menunukkan besarnya variansi variabel dependen yang dapat dijelaskan oleh variabel independennya. Dengan kata lain, koefisien determinasi ini digunakan untuk mengukur seberapa jauh variabel bebas dalam menerangkan variabel terikat. Niai koefisien determinasi ditentukan dengan nilai adjusted $R$ square sebagai mana dapat dilihat pada tabel 3.

\section{Tabel 4.17}




\section{Koefisien Regresi Linear Berganda}

Coefficients $^{\mathrm{a}}$

\begin{tabular}{|c|c|c|c|c|c|}
\hline \multirow[t]{2}{*}{ Model } & \multicolumn{2}{|c|}{$\begin{array}{c}\text { Unstandardized } \\
\text { Coefficients }\end{array}$} & \multirow{2}{*}{$\begin{array}{c}\text { Standardized } \\
\text { Coefficients } \\
\text { Beta }\end{array}$} & \multirow[t]{2}{*}{$\mathrm{T}$} & \multirow[t]{2}{*}{ Sig. } \\
\hline & B & Std. Error & & & \\
\hline (Constant) & 9,900 & 5,365 & & 1,845 & ,073 \\
\hline Motivasi & ,513 &, 157 & , 472 & 3,262 & ,002 \\
\hline 1 Komunikasi &,- 345 & , 178 &,- 339 & $\begin{array}{r}- \\
1.940\end{array}$ & ,060 \\
\hline $\begin{array}{l}\text { Budaya } \\
\text { organisasi }\end{array}$ & ,470 &, 137 & ,569 & 3,430 & ,001 \\
\hline
\end{tabular}

a. Dependent Variable: Kinerja

Sumber : Data primer yang diolah, 2016.

Hasil pada tabel 4 dapat dituliskan dalam model persamaan regresi linear berganda sebagai berikut : $\mathrm{Y}=9,900+0,470 \mathrm{X} 1-0,345 \mathrm{X} 2+0,513 \mathrm{X} 3+\mathrm{e}$

Tabel 4.18

\section{Hasil Uji Koefisiensi Determinasi}

\section{Model Summary}

\begin{tabular}{|l|c|r|r|r|}
\hline Model & $\mathrm{R}$ & $\begin{array}{c}\mathrm{R} \\
\text { Square }\end{array}$ & $\begin{array}{c}\text { Adjusted R } \\
\text { Square }\end{array}$ & $\begin{array}{c}\text { Std. Error of } \\
\text { the Estimate }\end{array}$ \\
\hline 1 &, $693^{\mathrm{a}}$ &, 480 &, 440 & 2,99489 \\
\hline
\end{tabular}

a. Predictors: (Constant), budaya organisasi,

komunikasi, motivasi

Sumber : Data primer yang diolah, 2016.

Hasil koefisien korelasi berganda adalah 0,693, sedangkan niai $r$ square adalah 0,480 atau 48\%. Hasil ini mengindikasikan bahwa $48 \%$ variabel Y dapat dijelaskan oleh variabel budaya organisasi, komunikasi,dan motivasi. Sisanya dipengaruhi oleh variabel lain.

\section{Analisis Data Regresi Linear Berganda}


Analisis regresi pada dasarnya adalah studi mengenai ketergantungan variabel dependen (Kinerja Pegawai) dengan variabel independen (Budaya Organisasi, Komunikasi, dan Motivasi), dengan tujuan untuk memprediksi perubahan nilai varibel terkait akibat pengaruh dari nilai variabel bebas. Perhitungan statistik dalam analisis regresi linier berganda ini menggunakan bantuan program SPSS. Hasil pengolahan data dengan menggunakan SPSS selengkapnya ada pada lampiran dan selnjutnya dijelaskan pada tabel berikut ini :

\section{Pengujian Hipotesis}

Tabel 4.19 perhitungan Uji-t

Coefficients ${ }^{\mathrm{a}}$

\begin{tabular}{|c|c|c|c|c|c|}
\hline \multirow[t]{2}{*}{ Model } & \multicolumn{2}{|c|}{$\begin{array}{c}\text { Unstandardized } \\
\text { Coefficients }\end{array}$} & \multirow{2}{*}{$\begin{array}{c}\begin{array}{c}\text { Standardized } \\
\text { Coefficients }\end{array} \\
\text { Beta }\end{array}$} & \multirow[t]{2}{*}{$\mathrm{T}$} & \multirow[t]{2}{*}{ Sig. } \\
\hline & B & Std. Error & & & \\
\hline (Constant) & 9,900 & 5,365 & & 1,845 & ,073 \\
\hline Motivasi & ,513 & , 157 & ,472 & 3,262 & ,002 \\
\hline 1 Komunikasi &,- 345 & , 178 &,- 339 & - & ,060 \\
\hline $\begin{array}{l}\text { Budaya } \\
\text { organisasi }\end{array}$ & ,470 & , 137 & ,569 & 3,430 & ,001 \\
\hline
\end{tabular}

a. Dependent Variable: SCOREKIN

Sumber : Data primer yang diolah, 2016.

Hasil Hipotesis Uji-t nya adalah sebagai berikut :

1. Hl : Budaya Organisasi (Xl) berpengaruh signifikan terhadap Kinerja Pegawai. Pada hipotesis pertama, $\mathrm{Hl}$ dalam penelitian ini menyatakan apakah terdapat hubungan yang signifikan antara Budaya Organisasi dengan Kinerja Pegawai. Variabel Budaya Organisasi (Xl) memiliki nilai signifikan 0,001 $<0,05$ artinya signifikan dan memiliki pengaruh yang positif. Maka secara parsial variabel Budaya Organisasi berpengaruh positif dan signifikan terhadap Kinerja Pegawai Kantor Camat Batam Kota. (Hl diterima). Hal ini mengindikasikan bahwa apabila variabel Budaya Organisasi ditingkatkan sebesar satu satuan, maka Kinerja Pegawai (Y) akan meningkat sebesar 0,470. 
2. H2 : Komunikasi (X2) berpengaruh tidak signifikan terhadap Kinerja Pegawai. Pada Hipotesis kedua, H2 dalam penelitian ini menyatakan apakah terdapat hubungan yang signifikan antara Komunikasi denga Kinerja Pegawai. Variabel Komunikasi (X2) memiliki nilai tidak signifikan $0,060<0,05$ artinya tidak signifikan dan memiliki pengaruh yang negatif. Maka secara parsial variabel Komunikasi berpengaruh negatif dan tidak signifikan terhadap Kinerja Pegawai Kantor Camat Batam Kota.(H2 ditolak). Hal ini mengidentifikasikan bahwa apabila variabel Budaya Organisasi ditingkatkan sebesar satu satuan, maka Kinerja Pegawai (Y) akan menurun sebesar -0,345.

3. H3 : Motivasi (X3) berpengaruh signifikan terhadap Kinerja Pegawai (Y). Pada hipotesis ketiga, H3 dalam penelitian ini menyatakan apakah terdapat hubungan yang signifikan antara Motivasi dengan Kinerja Pegawai. Variabel Motivasi (X3) memiliki signifikan $0,002<0,05$ artinya signifikan. Maka secara parsial variabel motivasi berpengaruh positif dan signifikan terhadap Kinerja pegawai Kantor Camat Batam Kota. (H3 diterima).

Hal ini mengindikasikan bahwa apabila variabel Motivasi ditingkatkan sebesar satu satuan, maka Kinerja Pegawai (Y) akan meningkat sebesar 0,513.

Tabel 4.20 Model Uji Simultan

ANOVA ${ }^{\mathrm{a}}$

\begin{tabular}{|c|c|c|c|c|c|c|}
\hline \multicolumn{2}{|c|}{ Model } & $\begin{array}{l}\text { Sum of } \\
\text { Squares }\end{array}$ & Df & $\begin{array}{l}\text { Mean } \\
\text { Square }\end{array}$ & $\mathrm{F}$ & Sig. \\
\hline \multirow{3}{*}{1} & Regression & 322,382 & 3 & 107,461 & 11,981 &, $000^{b}$ \\
\hline & Residual & 349,804 & 39 & 8,969 & & \\
\hline & Total & 672,186 & 42 & & & \\
\hline
\end{tabular}

a. Dependent Variable: Kinerja

b. Predictors: (Constant), Budaya organisasi, Komunikasi, Motivasi

Sumber : Data primer yang diolah, 2016.

Dari data diatas dapat dilihat bahwa nilai probabilitas F (sig) variabel independen secara simultan (Budaya Organisasi, Komunikasi dan Motivasi) terhadap variabel independen adalah 0,000 (sig.0 < 0,05) maka Ho ditolak dan Ha diterima. 


\section{KESIMPULAN DAN SARAN}

\section{Kesimpulan}

1. Dari uji hipotesis diketahui bahwa Budaya Organisasi(X1) mempunyai determinasi yang signifikan terhadap kinerja pegawai (Y) pada taraf signifikansi sebesar 0.001 yang mana angka ini dibawah level of significance yang digunakan yaitu 0.05 , sehingga disimpulkan $\mathrm{H} 1$ diterima.

2. Uji hipotesis diketahui bahwa Komunikasi (X2) mempunyai determinasi yang tidak signifikan terhadap kinerja pegawai (Y) pada taraf signifikansi sebesar 0,060 yang mana angka ini berada diatas level of significance yang digunakan yaitu 0.05 , sehingga disimpulkan $\mathrm{H} 2$ ditolak.

3. Berdasarkan uji hipotesis juga diketahui bahwa Motivasi (X3) mempunyai determinasi yang signifikan terhadap kinerja pegawai (Y) pada taraf signifikan 0,002 yang mana angka ini berada dibawah level of significance yang digunakan yaitu 0.05 , sehingga disimpulkan $\mathrm{H} 3$ diterima.

4. Uji hipotesis disimpulkan bahwa budaya organisasi dan motivasi secara simultan siginifikan terhadap kinerja pegawai, sedangkan Komunikasi secara simultanmempunya i determinasi yang tidak signifikan terhadap kinerja pegawai.

\section{Saran}

1. Pada penelitian ini diketahui bahwa budaya organisasi belum sepenuhnya berjalan dengan baik di Kantor Camat Batam Kota, Oleh karena itu, disarankan kepada pegawai Kantor Camat Batam Kota agar budaya organisasi lebih ditingkatkan untuk menciptakan kinerja pegawai yang lebih baik lagi. Dan Pegawai Kantor Camat Batam Kota selalu dilibatkan dalam pengambilan keputusan, dimana didalam suatu organisasi perlu kesepakatan bersam agar tidak terjadi keputusan di sebelah pihak saja. Kemudian Pegawai Kantor Camat Batam Kota hendaknya selalu membantu ketika ada teman sesama pegawai yang kesulitan, disinilah timbul peran Budaya organisasi agar timbul rasa saling tolong menolong sesama ketika ada kesulitan.

2. Pada penelitian ini juga diketahui bahwa komunikasi perlu ditingkatkan, mengingat peningkatan ini akan membawa lebih baik lagi pengaruhnya terhadap kinerja pegawai di kantor Camat Batam Kota. Seperti pegawai hubungan baik antara pegawai, ini sangat diperlukan karena akan timbul rasa saling meghormati 
dan menjaga komunikasi dengan baik. Kemudian pegawai Kantor Camat Batam Kota haruslah ramah dan menghormati atasan.

3. Untuk masalah motivasi disini diharpakan atasan mengerti dengan keluh kesah yang disampaikan oleh para pegawai, agar pegawai merasa termotivasi dan diberi semangat oleh atasannya. Ketika para pegawai (bawahan) ada keperluan diluar kantor hendaknya mendapat pengertian dari atasan. Jika para pegawai menyelesaikan tugasny tepat waktu, hendaknya di beri reward yang setimpal dengan apa yang sudah dikerjakan, agar kedepannya para pegawai lebih giat dan termotivasi lagi untuk mengerjakan tangung jawab mereka lebih baik lagi.

\section{DAFTAR PUSTAKA}

Adam,Ami. 2009. Pengaruh Kepemimpinan, Motivasi dan Lingkungan Kerja terhadap Kinerja Karyawan. $P T$ KAI DOP1 Skripsi Jakarta:Universitas Indonesia Jakarta.

Ananto,Reza. 2014. Analisis Pengaruh Gaya Kepemimpinan, Motivasi dan Disiplin

Kerja terhadap Kinerja Pegawai. PT DHL Global Forwarding” Skripsi

Semarang:Universitas Dipenogoro Semarang.

Astary,Putri. 2014. Pengaruh Karakteristik Pekerjaan dan Gaya Kepemimpinan

Terhadap Komitmen Organisasi. Pada PT KAEFER” Skripsi Batam:Universitas Batam.

Effendi Usman. (2014). Asas Manajemen. Jakarta: Penerbit PT. RajaGrafindo Persada.

Fahmi,Irham. 2011. Manajemen Kepemimpinan : Teori \& Aplikasi. Bandung: Alfabeta.

Fattah Hussein. (2014). Perilaku Pemimpin dan Kinerja Pegawai. Yogyakarta: Penerbit Elmatera.

Fahmi Irham. (2013). Perilaku Organisasi. Bandung: Penerbit Alfabeta.

Ghozali,Imam. 2006. Statistik Nonparametrik. Semarang: Badan Penerbit UNDIP.

Ghozali,Imam. 2006. Structural Equation Modeling Metode Alternatif dengan

Partial Least Square. Semarang: Badan Penerbit UNDIP.

Gitosudarmo \& Mulyono. 2006. Prinsip Dasar Manajemen. Yogyakarta:BPFE 
Herlambang Susatyo. (2014. Perilaku Organisasi. Yogyakarta. Penerbit KDT.

Harijono, Hendra. 2011. Pengaruh Gaya Kepemimpinan dan Kompensasi Terhadap Kinerja Kerja Pegawai Pada Bandara Hang Nadim Batam. Thesis Magister Sains Manajemen Universitas Batam. Hal 20-30.

Kusumawati,Ratna. 2008. Analisis Pengaruh Budaya Organisasi dan Gaya Kepemimpinan Terhadap Kepuasan Kerja untuk meningkatkan Kinerja Karyawan RS.Roemani. Tesis Semarang:Universitas Dipenogoro Semarang.

Ma'arif \& Kartika. 2012. Manajemen Kinerja Sumber Daya Manusia. Bogor: IPB Press.

Mangkunegara. 2013. Manajemen Sumber Daya Manusia Perusahaan. Bandung: PT Remaja Rosdakarya Offset.

Mulyadi Deddy. (2015). Perilaku Organisasi dan Kepemimpinan Pelayanan. Bandung: Alfabeta.

Rumengan Jemmy. (2010). Metodologi Penelitian Dengan SPSS. Batam. Penerbit universitas Batam Press.

Sujarweni. 2014. Metodologi Penelitian. Pustaka Baru Press:Yogyakarta.

Sujarweni. 2015. Metodologi Penelitian Bisnis \& Ekonomi. Yogyakarta: Pustaka Baru Press.

Sutrisno,Edy. 2009. Manajemen Sumber Daya Manusia. Jakarta: Kencana.

Sunyonto Danang. (2015). Teori Perilaku Kerorganisasian.Yogyakarta: Penerbit Caps.

Sunyonto Danang .(2013). Perilaku Organisasional. Jakarta: Penerbit CAPS (Center Academic Publishing Service).

Sutrisno Edy .(2009).Manajemen Sumber Daya Manusia. Jakarta: Penerbit Kencana Prenada Media Group

Sugiyono. (2013). Metode Penelitian Manajemen. Yogyakarta: Penerbit Alfabeta. Torang Syamsir. (2013). Organisasi dan Manajemen. Bandung: Penerbit Alfabeta. Wibowo. (2014). Manajemen Kinerja. Jakarta: Penerbit PT RajaGrafindo Persada. Zainal dkk. (2014). Kepemimpinan dan Perilaku Organisasi. Jakarta: Penerbit PT. RajaGrafindo Persada. 
